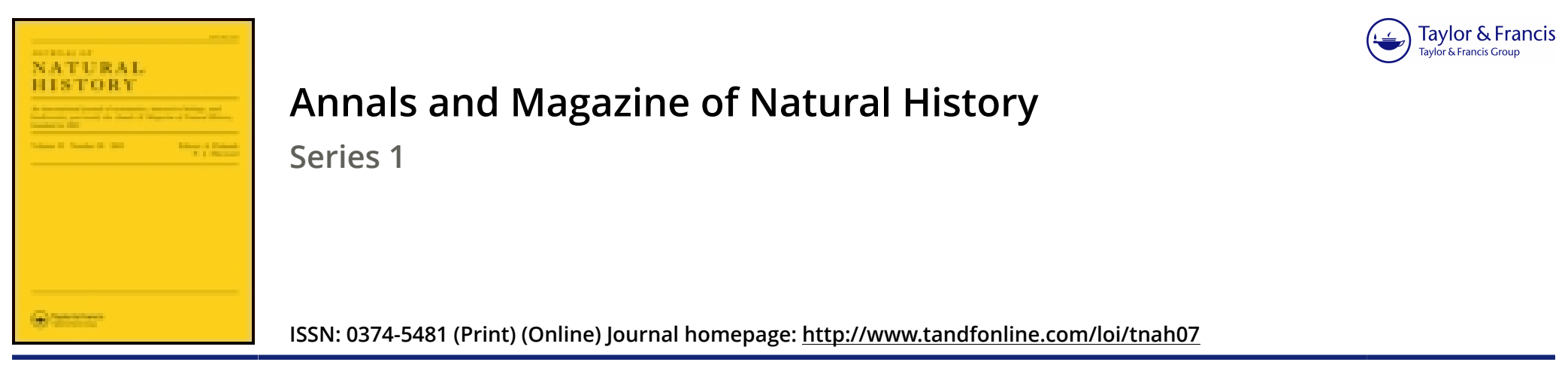

\title{
XXVII.-On the penetration of the cuticle into the stomata
}

\section{Hugo von Mohl}

To cite this article: Hugo von Mohl (1845) XXVII._On the penetration of the cuticle into the stomata, Annals and Magazine of Natural History, 15:98, 217-221, DOI: 10.1080/037454809495303

To link to this article: http://dx.doi.org/10.1080/037454809495303

册 Published online: 23 Dec 2009.

Submit your article to this journal $₫$

Q View related articles $\sqsubset$ 


\title{
THE A N N L S
}

AND

\section{MAGAZINE OF NATURAL HISTORY.}

\author{
No. 98. APRIL 1845.
}

\section{XXVII.-On the Penetration of the Cuticle into the Stomata. By Hugo von MoHL*.}

Three observers have nearly at the same time, and perfectly independent of one another, discussed a point which, notwithstanding the numerous investigations made respecting the stomata, had hitherto been entirely overlooked in their anatomy; they are, however, far from agreeing in the descriptions they give of the circumstance discovered by them.

Gugliemo Gasparrinit states, that beneath the stomata of the stem of Cactea, in particular of Cereus peruvianus, of the stem of Euphorbia officinarum, and of herbaceous leaves, there is situated a vesicular organ, which he terms Cistoma. Its walls are said to consist of delicate fibres connected by a membrane, which form a sphincter at the upper end of the cistoma, situated beneath the closed aperture of the stoma. The vesicular organs the author separated with the cuticle from the epidermis by boiling the latter in dilute nitric acid.

Hartig, in his 'Lehrbuch der Pflanzenkunde,' part 4, 1842, describes the same organ as an appendage of the cuticle. To the latter he ascribes a very complicated structure, separating it into three different layers: 1 . an external membrane, epichroa; 2. an internal membrane, endochroa; 3. a central mass situated between these membranes, the central cement, mesocolla. It is stated of the external membrane, that it extends over the entire leaf, penetrates into the area in front of the stomata, but nevertheless continues further over the stoma itself without interruption, while the inner membrane is immersed in the form of folds between the cells of the epidermis and penetrates in various plants, more or less deeply into the subjacent cellular tissue, in which case it then takes its course through the intercellular passages in the form of vessels (intercellular vessels). In like manner the inner

- From the Botanische Zeitung for Jan. 3, 1845. Translated and communicated by W. Francis, Ph.D., F.L.S.

+ Rendiconto delle adunanze e dei lavori dell' Academia delle Scienze, Napoli, 1842.

Ann. Mag. N. Hist. Vol. xv. 
membrane is said to penetrate through the stomata into the spiracles, clothe their walls, and extend thence, in the leaves of Narcissus Jonquilla, in the form of vessels into the intercellular passages.

Payen* statcs that the cuticle enters the stomata and, in Cactus peruvianus, extends down through the layers of the epidermis as a thin membrane in the form of a muff. This membrane, like the cuticle itself, is said to be coloured yellow by iodine, and to exhibit the same resistance to the action of sulphuric acid.

These statements induced me to institute some investigations on the subject in question. For this purpose I adopted the method of soaking the sections of the leaves for examination in tincture of iodine, washing them with water, and then submitting them to the action of sulphuric acid. This latter not only heightens the yellow tint of the cuticle coloured by iodine, but it has especially this advantage, that the cells of the epidermis of most plants are disintegrated with the production of a blue colouring or entirely dissolved, according to the strength of the acid employed, when the cuticle can be very readily distinguished and separated from them. From these investigations this general result was obtained, that, as asserted by Payen, a direct continuation of the cuticle penetrates into the stomata and proceeds down between the porous cells to the spiracles in the form of a tube very highly compressed on both sides. No doubt can be entertained, on a careful examination, that this tube is not closed either at the entrance into the stomata or lower down between the porous cells. Arrived at the inner termination of the stomatic aperture, this tube dilates into a smaller or larger funnelshaped expansion, which clothes the inferior surface of the epidermis so far as it closes the spiracle externally.

Some differences occur with respect to this funnel-shaped expansion in various plants. Generally the expansion of the funnel extends only as far as true cells of the epidermis form the outer wall of the spiracles; and it is cut off short at the limit of the outer wall and of the lateral walls of the spiracles formed of green parenchymatous cells, so that the margin of the funnel presents irregularities corresponding to the rounded-off lateral walls of the parenchymatous cells. In general no appendages penetrate from the margin of the funnel into the intercellular passages running beneath the epidermis and connected with the spiracles; for instance, in the stem of Euphorbia officinarum, Cacalia Kleinia, Lepismium Myosurus, in the leaves of Agapanthus umbellatus, Narcissus Jonquilla, Pothos lanceolata, and in the leaf-like branches of Ruscus aculeatus. In other cases, on the contrary, appendages proceed from the margin of the funnel-shaped expansion through

* Mémoire sur le Développement des Végétaux. 
the intercellular passages on the inferior surface of the epidermis to neighbouring funnels, and form in this manner counexions with one another; for instance, on the under side of the leaves of Helleborus niger and viridis, and in the leaves of Euphorbia Caput Medusa. Lastly, it occurs in some plants, for instance, in the leaves of Betula alba and Asphodelus luteus, that such appendages penetrate into all the intercellular passages situate beneath the epidermis, and extend in the form of a reticulate membrane over the whole under surface of the epidermis, so that the epidermatous cells are clothed on both sides by a true cuticle, in which the inner cuticle does not, it is true, form a continuous membrane, not passing in between the epidermatous cells and the parenchymatous cells adherent to them, but exhibiting at the place of connexion of every parenchymatous cell with a cell of the epidermis, a void corresponding to the size of the place of connexion. A similar inner perforated cuticle may likewise occur without the epidermis being interrupted by stomata; but this is rare, at least I have hitherto found it only in the epidermatous cells of the upper surface of the leaf of Helleborus niger and viridis.

When the epidermis consists of several superposed layers of cells, as in Cereus peruvianus and Cactus Opuntia, the continuation of the cuticle clothes the lateral walls of the portion of the spiracle situated in this thickened epidermis ; it consequently appears not merely in the form of a wide expanded funnel, but rather in that of a tube, and then constitutes the organ described and figured by Gasparrini under the name of cistoma. In this case the tube-like continuation of the cuticle likewise terminates with an open embouchure at the inferior limit of the epidermis; although it sometimes appeared to me to continue for a short distance into the portion of the spiracle situated between the green parenchymatous cells; for instance, in Cereus peruvianus and likewise in Protea mellifera, whose leaves, moreover, possess a simple epidermis.

This continuation of the cuticle penetrating into the interior of the organs, is acted upon, as already observed by Payen, by iodine and sulphuric acid precisely like the cuticle situated on the outer side of the epidermis. A composition of fibres, which is ascribed to it by Gasparrini, can no more be demonstrated in it than in any other vegetable membrane; but just in like manner as fibre-like thickened bands occur on the cuticle of many plants, so do we find the same circumstance in some of the plants I have examined; for instance, Cereus peruvianus and Helleborus niger, and likewise on the fumnel-shaped membrane clothing the outer side of the spiracles. As, moreover, the cuticle of most plants does not admit of our distinguishing any composition of individual pieces correspondent to the subjacent epidermatous cells, so is it 
likewise with their appendages situated in the interior of the leaf. It is true they sink into the furrows proceeding between the adjacent cells, and are frequently provided at these places with projecting bands immersed in the furrows; but a composition of originally distinct pieces is in so far incapable of being detected, as it is impossible to separate them into the individual pieces corresponding to these divisions by the application of acids. This circumstance will naturally be considered by those phytotomists who, with Treviranus, Schleiden and Payen, look upon the cuticle as a part distinct from the epidermatous cells, as a hardened secretion, to support their view; but in reference to this point, it is in my opinion requisite to take the greatest precaution not to be led to a rash conclusion.

I have already in my memoir on the cuticle, ' Linnæa,' vol. xvi., not by any means denied that important reasons appear to speak in favour of this view, and I am at present just as far from wishing to deny the possibility that this view is correct and the one supported by me erroneous; but nevertheless I still believe, that the view according to which the cuticle is formed of the outer layers of the epidermatous cells themselves is far more probable. If the cuticle owed its origin to a secretion taking place at the surface of the epidermis, it ought to be possible to find the primary membrane of the epidermatous cells beneath it, and observe it pass into the lateral walls of these cells. I have not succeeded in doing this, but, on the contrary, I believe I have traced in many cases the primary membrane of the lateral walls of the epidermatous cells through the cuticle to the surface of the latter, and I thence concluded that the cuticle was not a peculiar membrane distinet from the epidermis, but owed its peculiarities to a metamorphosis of the substance of the outer layers of the epidermatous cells themselves. Undoubted analogies may be adduced in support of such metamorphoses of individual parts of the cell-wall (or according to the views of Payen, in favour of a deposition of organic substances in the cellulose of the original cell-wall, whence this acquires different properties). I would especially call to mind, in this respect, the nature of the primary membrane of the prosenchymatous cells of most woods, which membrane originally exhibited all the characters of pure cellulose, while in the developed wood it presents the same property as the cuticle, of being coloured yellow by iodine and of resisting the action of sulphuric acid. I would moreover call to mind the brown-coloured parenchymatous cells which inclose the vascular bundles of ferns, and in which, in some cases, not all the walls, but only that directed towards the vascular bundle and a portion of the lateral wall, undergoes that metamorphosis into a thickened brown substance resisting the action of sulphuric 
acid. But whatever be the case with regard to the origin of the cuticle, I must certainly protest most decidedly against Hartig's representation that the cuticle consists of three layers, and that the membranes penetrating into the interior of the leaf are a continuation of only one of these layers, the innermost, and that they form hollow, vessel-like tubes in the intercellular passages, since I have not observed a single circumstance that would afford a confirmation of any one of these statements.

XXVIII.-Researches into the Structure, Functions and Economy of the Araneidea. By John Blackwall, F.L.S.*

In essaying to give an epitome of some investigations recently made in this country relative to the organization, physiology and œeconomy of the Araneidea, I shall endeavour to accomplish the undertaking in as compendious a manner as may be deemed compatible with a perspicuous statement of the various facts to be detailed, distinguishing those already before the public from such as are not by references to the works in which they have appeared.

Without further preface, I proceed to the consideration of those remarkable appendages termed scopula or brushes, with which the tarsi of numerous species of spiders are provided. This apparatus, consisting of coarse, compound, hair-like papillæ either distributed along the inferior surface of the tarsi or situated immediately below the claws at their extremity, bears a close analogy to the tarsal cushions of insects, enabling its possessor to ascend the perpendicular surfaces of highly polished bodies and even to adhere to smooth objects in an inverted position by the emission of a viscous secretiont. The different plans according to which the papillæa are disposed upon the tarsi are respectively represented by two common British spiders, Drassus sericeus and Salticus scenicus.

Some of the spiders belonging to the families Theridiida and Epëiridce have the sides and lower part of the tarsi, at their extremity, supplied with several small, curved, dentated claws, in addition to the three larger ones common to them all. Epëira quadrata, Epeira apoclisa, and, indeed, most of the larger species of Epëirce indigenous to Great Britain, exhibit this structure to advantage under the microscope; they have, besides, a strong, moveable spine, inserted near the termination of the tarsus of each posterior leg, on the under side, which curves a little upwards at its extremity, and presents a slight irregularity of outline at its superior surface. These spines, which have been denominated sustentacula, subserve an important purpose. By the contraction of their flexor muscles they are drawn towards the foot, and are thus brought into direct opposition to the claws, by which means the animals are enabled to hold with a firm grasp such lines as they have occasion to draw from the spinners

* From the Report of the Meeting of the British Association held at York 1844.

$\uparrow$ Transactions of the Linnæan Society, vol. xvi. pp. 768, 769. Researches in Zoology, p. 289. 